\title{
PENGEMBANGAN BAHAN AJAR FISIKA EKSPERIMEN BERBASIS PROYEK UNTUK MENINGKATKAN KETERAMPILAN BERPIKIR KRITIS CALON GURU FISIKA
}

\author{
Sutrio*, Gunawan, Ahmad Harjono, Hairunnisyah Sahidu \\ Program Studi Pendidikan Fisika, Universitas Mataram \\ *Email: sutrio_trio@unram.ac.id
}

\begin{abstract}
This research aims to develop project-based teaching materials of experimental Physics that can improve the critical thinking skills of prospective teachers. This research includes development of education which is divided into three phases, namely preliminary study phase, product design development phase, and product testing phase. The results showed that the teaching materials that have been developed feasible / well used in learning and meet the validation test by the expert for the contents' feasibility, presentation and language with good category. Students' response after using the teaching materials is very good to support and complete the teaching materials at the time of lecturing. The teaching materials which tested in experimental Physics II were able to improve students' critical thinking skills from the initial test result with the mean score of 38.1 and the final test result with the mean score of 69.8 .
\end{abstract}

Keywords: project-based teaching materials, experimental Physics, Critical thinking skills

\section{PENDAHULUAN}

FKIP Universitas Mataram sebagai lembaga pencetak tenaga pendidik profesional mempunyai tugas pokok dalam menyelenggarakan pendidikan untuk calon tenaga kependidikan dan terus mengupayakan melaui program unggulan yang terencana dan terkoordinasi dengan baik untuk meningkatkan kualitas mutu lulusannya. Hal ini untuk mencapai kompetensi lulusan sebagaimana yang diharapkan dalam Standar Nasional Pendidikan Tinggi, maka harus didukung dengan kualitas standar proses pembelajaran yang bersifat interaktif, holistik, integratif, saintifik, kontekstual, tematik, efektif, kolaboratif, dengan menekankan interaksi antara dosen, mahasiswa, dan sumber belajar. Proses belajar mengajar terjadi sedikitnya melibatkan tiga komponen, yaitu pebelajar (mahasiswa), pengajar (dosen), dan materi pembelajaran. Bahkan dengan kemandirian mahasiswa, proses belajar dapat terjadi tanpa kehadiran pengajar (dosen). Dengan demikian, penyediaan buku ajar akan sangat membantu mahasiswa dalam belajar dan membantu dosen untuk mengajar lebih efektif dan efisien sehingga waktu yang tersedia dapat digunakan untuk membimbing mahasiswa lebih intensif dan melakukan latihan-latihan yang diperlukan untuk pengembangan, yang pada akhirnya akan bermuara pada percepatan penguasaan capaian pembelajaran mata kuliah dari mata kuliah bersangkutan.

Fisika Eksperimen II merupakan salah satu mata kuliah wajib yang harus ditempuh oleh mahasiswa di Program Studi Pendidikan Fisika FKIP Universitas Mataram. Mata kuliah ini memiliki capaian pembelajaran dimana mahasiswa dituntut untuk membuat suatu karya laboratorium yang dapat dipergunakan untuk kegiatan praktikum di sekolah menengah. Dalam pelaksanaan perkuliahan, mahasiswa diharapkan memiliki kemampuan untuk memilih sendiri judul karya laboratorium dan membuat perencanaan pembuatan alat, serta uji coba alat dan mengkomunikasikan hasil, oleh karena itu perlu dibuatkan panduan bahan ajar Fisika Eksperimen berbasis proyek sebagai alternatif yang 
dipandang mampu meningkatkan pemahaman konsep, keterampilan berpikir kritis, bekerja secara aktif dan kolaboratif.

Pembelajaran berbasis proyek merupakan pembelajaran yang berpusat pada proses, relatif berjangka waktu, berfokus pada masalah, unit pembelajaran bermakna dengan memadukan konsepkonsep dari sejumlah komponen baik itu pengetahuan, disiplin ilmu atau lapangan. Pada pembelajaran berbasis proyek kegiatan pembelajarannya berlangsung kolaboratif dalam kelompok heterogen. Pembelajaran berbasis proyek memiliki potensi yang sangat besar untuk melatih proses berpikir mahasiswa yang mengarah pada keterampilan berpikir kritis mahasiswa. Keterampilan berpikir kritis dikembangkan di setiap tahapan pembelajaran berbasis proyek. Mahasiswa menjadi terdorong di dalam belajar mereka, dosen berperan sebagai mediator dan fasilitator.

Dalam era globalisasi dewasa ini, tantangan peningkatan mutu dalam berbagai aspek kehidupan tidak dapat ditawar lagi. Pesatnya perkembangan IPTEKS dan tekanan globalisasi yang menghapuskan tapal batas antarnegara, mempersyaratkan setiap bangsa untuk mengerahkan pikiran dan seluruh potensi sumber daya yang dimilikinya untuk bisa survive dan bahkan exel dalam perebutan pemanfaatan kesempatan dalam berbagai sisi kehidupan. Ini berarti perlu adanya peningkatan sikap kompetitif secara sistematik dan berkelanjutan suber daya manusia melalui pendidikan dan pelatihan. Oleh karena itu, pendidikan dewasa ini harus diarahkan pada peningkatan daya saing bangsa agar mampu berkompetisi dalam persaingan global. Hal ini bisa tercapai jika pendidikan di LPTK diarahkan tidak semata-mata pada penguasaan dan pemahaman konsep-konsep ilmiah, tetapi juga pada peningkatan kemampuan dan keterampilan beripikir mahasiswa , khususnya keterampilan berpikir tingkat tinggi yaitu keterampilan berpikir kristis (critical thinking skills). Artinya, pengajar perlu mengajarkan peserta didiknya untuk belajar berpikir (teaching of thinking).

Kehidupan dalam era globalisasi dipenuhi oleh kompetisi-kompetisi yang sangat ketat. Keunggulan dalam berkompetisi terletak pada kemampuan dalam mencari dan menggunakan informasi, kemampuan analitis-kritis, keakuratan dalam pengambilan keputusan, dan tindakan yang proaktif dalam memanfaatkan peluangpeluang yang ada. Oleh karena itu, maka kemampuan berpikir formal peserta didik yang mencakup kemampuan berpikir hipotetik-deduktif, kemampuan berpikir proporsional, kemampuan berpikir kombinatorial, dan kemampuan berpikir reflektif sebagai kemampuan berpikir dasar, perlu dijadikan sebagai substansi yang harus digarap secara serius dalam dunia pendidikan. Kemampuan berpikir dasar ini harus terus dikembangkan menuju kemampuan dan keterampilan berpikir kritis (critical thinking skills). Berpikir kritis (critical thinking) merupakan topik yang penting dan vital dalam era pendidikan modern (Schafersman, 2006). Tujuan khusus pembelajaran berpikir kritis dalam pendidikan sains maupun disiplin yang lain adalah untuk meningkatkan keterampilan berpikir peserta didik dan sekaligus menyiapkan mereka agar sukses dalam menjalani kehidupannya. Dengan dimilikinya kemampuan berpikir kritis yang tinggi oleh peserta didik maka mereka akan dapat mencapai standar kompetensi yang telah ditetapkan dalam kurikulum, serta mereka akan mampu merancang dan mengarungi kehidupannya pada masa datang yang penuh dengan tantangan, persaingan, dan ketidakpastian.

Penelitian ini dimaksudkan untuk mengembangkan bahan ajar yang dipandang memberi kontribusi yang signifikan dalam 
pengembangan keterampilan berpikir kritis mahasiswa; mendeskripsikan jenis intrumen asesmen yang digunakan dalam mengukur keterampilan berpikir kritis mahasiswa; dan mendeskripsikan kualitas keterampilan berpikir kritis. Untuk mengembangkan kemampuan dan keterampilan berpikir kritis peserta didik dalam proses pembelajaran perlu dilakukan strategi-strategi sebagai berikut (Meyers, 1986). Pertama, Menyeimbangkan antara konten dan proses, dalam penyajian materi pelajaran agar diseimbangkan antara konten dan proses. Dalam pelajaran sains, harus seimbang antara sains sebagai produk (penyajian fakta, konsep, prinsip, hukum, dsb) dan sains sebagai proses (keterampilan proses sains), seperti mengobsevasi kejadian, merumuskan masalah, berhipotesis, mengukur, menyimpulkan, dan mengontrol variabel. Kedua, Seimbangkan antara ceramah (lecture) dan diskusi (interaction), teori belajar Piaget menekankan bahwa pentingnya transmisi sosial dalam mengembangkan struktur mental yang baru. Ketiga, Ciptakan diskusi kelas, guru sebaiknya memulai presentasi dengan "pertanyaan" Ajukan pertanyaan yang dapat mengkreasi suasana antisipasi dan inkuiri.

$$
\text { Penjelasan langkah-langkah }
$$

perkuliahan Fisika Eksperimen II Berbasis Proyek sebagai berikut.

\section{Penentuan Judul Proyek}

Mahasiswa membentuk kelompok yang beranggotakan $3-5$ orang dan berdiskusi menentukan judul proyek yang dipilih. Judul proyek diutamakan memilih sendiri dengan mengkaji literatur secara mendalam agar judul yang dipilih nantinya secara nyata dapat dilaksanakan. Judul yang sudah dipilih diajukan kepada dosen untuk disetujui. Bagi mahasiswa yang kesulitan menemukan judul proyek bisa memilih judul alternatif yang sudah ada di dalam bahan ajar. (Minggu ke-1 dan Minggu ke-2).

\section{Mendesain Perencanaan Proyek}

Mahasiswa bersama anggota kelompoknya membuat perencanaan proyek yang akan dikerjakan dan berkonsultasi dengan dosen. Dengan demikian mahasiswa diharapkan akan merasa "memiliki" atas proyek tersebut. Perencanaan berisi tentang aturan main, pemilihan aktivitas yang dapat mendukung dalam menjawab pertanyaan esensial, dengan cara mengintegrasikan berbagai subjek yang mungkin, serta mengetahui alat dan bahan yang dapat diakses untuk membantu penyelesaian proyek. (Minggu 3 dan 4)

\section{Pelaksanaan Proyek}

Mahasiswa melaksanakan proyek yang sudah direncanakan yaitu membuat karya laboratorium yang berupa alat atau set alat yang akan digunakan untuk percobaan/praktikum di sekolah menengah. Dosen dan mahasiswa secara kolaboratif menyusun jadwal aktivitas dalam menyelesaikan proyek. Aktivitas pada tahap ini antara lain: (1) membuat timeline untuk menyelesaikan proyek, (2) membuat deadline penyelesaian proyek, membimbing mahasiswa ketika mereka kesulitan dalam membuat karya laboratorium, (4) meminta mahasiswa untuk membuat mengambil cara lain dan meminta penjelasan (alasan) tentang pemilihan suatu cara, (5) dosen bertanggungjawab untuk melakukan monitor terhadap aktivitas mahasiswa selama menyelesaikan proyek. Monitoring dilakukan dengan cara menfasilitasi mahasiswa pada setiap proses. Agar mempermudah proses monitoring, dibuat sebuah rubrik yang dapat merekam keseluruhan aktivitas yang penting. (Minggu 5-8).

\section{Menguji coba hasil karya laboratorium}

Mahasiswa menguji hasil karya laboratoriumnya dengan melakukan percobaan/ pratikum dengan menggunakan alat atau set alat yang dibuat dengan petunjuk percobaan yang telah disusun oleh 
mahasiswa. Pada kegitan ini mahasiswa menerapkan langkah-langkah melaksanakan pratikum dengan metode ilmiah yang sudah diberikan di matakuliah sebelumnya. Setelah selesai melakukan praktikum mahasiswa membuat laporan secara tertulis berkaitan dengan proyek yang telah dilaksanakan. (Minggu 9 - 10)

\section{Mengkomunikasikan Hasil}

Mahasiswa mengkomunikasikan hasil proyek yang telah dibuat dalam forum diskusi pleno di kelas. Masing masing kelompok mempresentasikan hasil proyeknya dan kelompok lain mengajukan pertanyaan atau mengajukan pendapat sehubungan dengan proyek yang telah dibuat. Dosen memberi umpan balik tentang tingkat pemahaman yang sudah dicapai mahasiswa. (Minggu 11 -15)

\section{Mengevaluasi Pengalaman (Evaluate the Experience)}

Pada akhir proses perkuliahan, dosen dan mahasiswa melakukan refleksi terhadap aktivitas dan hasil proyek yang sudah dijalankan. Proses refleksi dilakukan baik secara individu maupun kelompok. Pada tahap ini mahasiswa diminta untuk mengungkapkan perasaan dan pengalamanya selama menyelesaikan proyek. Dosen dan mahasiswa mengembangkan diskusi dalam rangka memperbaiki kinerja selama proses perkuliahan, sehingga pada akhirnya ditemukan suatu temuan baru (new inquiry) untuk menjawab permasalahan yang diajukan pada tahap pertama pembelajaran. (Minggu 16)

\section{METODE PENELITIAN}

Penelitian ini merupakan penelitian pengembangan pendidikan (Educational Research and Development) yang disingkat dengan R \& D. Jenis penelitian R \& D adalah suatu proses yang digunakan untuk mengembangkan dan memvalidasi produkproduk pendidikan (Sugiyono, 2008).
Produk yang dimaksud dalam penelitian ini adalah bahan ajar Fisika Eksperimen Berbasis Proyek untuk perkuliahan Fisika Eksperimen II. Penelitian ini dilaksanakan di kelas perkuliahan Fisika Eksperimen II Program Studi Pendidikan Fisika FKIP Unram semester Genap Tahun Akademik 2016/2017. Subyek penelitian adalah mahasiswa yang menempuh kuliah Fisika Eksperimen II kelas A yang ber jumlah 32 orang.

Pengembangan bahan ajar dalam penelitian ini berpedoman pada Panduan Penulisan Buku Ajar yang disusun oleh Tim Pengembangan Buku Ajar FKIP Universitas Mataram tahun 2015 dengan kriteria: 1) isi buku ajar harus memberi peluang kepada peserta didik untuk mengembangkan beberapa keterampilan, 2) buku ajar memiliki capaian pembelajaran yang jelas, 3) kejelasan dan kebenaran konsep, 4) sesuai dengan kurikulum yang berlaku, 5) menarik minat peserta didik, 6) menumbuhkan motivasi dan menstimulasi aktivitas serta kemampuan berfikir mahasiswa , 7) ilustrasi dan contoh, 8) penggunaan bahasa yang komunikatif, logis dan sitemis, 9) kontekstual dan mutakhir, 10) menghargai perbedaan individu, 11) memantapkan nilainilai.

Penelitian dan pengembangan bahan ajar Fisika Eksperimen berbasis proyek ini meliputi 6 tahap yang diadaptasi dari 10 tahap dari penelitian pengembangan Borg dan Gall (Sugiyono, 2008). Adapun 6 tahapan yang diadopsi meliputi: 1) Analisis potensi dan masalah 2) Pengumpulan data; 3) Desain produk; 4 ) Validasi desain dan Revisi Desain; 5) Ujicoba Produk; 6) Analisis dan Pelaporan.

Pada awal kegiatan dilakukan analisis potensi dan masalah dalam pembelajaran Fisika Eksperimen dan dilanjutkan pengumpulan data dengan melakukan studi literatur tentang pembelajaran berbasis proyek dan 
kemampuan berpikir kritis. Dari data-data yang diperoleh dianalisis dan dijadikan acuan untuk membuat desain bahan ajar. Produk yang dihasilkan pada penelitian ini adalah bahan ajar bagi mahasiswa yang akan digunakan dalam pembelajaran yang akan digunakan untuk meningkatkan kemampuan berpikir kritis. Sebelum digunakan bahan ajar perlu diketahui kelayakan dengan melakukan penilaian kelayakan bahan ajar oleh ahli dengan cara memberikan tanggapan dengan kriteria sangat baik, baik, kurang baik, dan tidak baik. Uji coba produk bahan ajar diterapkan pada perkuliahan Fisika Eksperimen II dan dilakukan observasi keterlaksanaan pembelajaran Fisika Eksperimen berbasis proyek. dan di akhir perkuliahan mahasiswa diberikan angket untuk mengetahui tanggapan mahasiswa terhadap pembelajaran yang dilaksanakan.

Instrumen yang digunakan untuk mengumpulkan data dalam penelitian ini yaitu: 1) Angket skala Likert, terdiri dari angket uji validasi ahli dan angket respon mahasiswa terhadap pembelajaran yang dilaksanakan. Angket uji validasi dimaksudkan untuk memvalidasi desain bahan bahan ajar yang digunakan oleh ahli untuk mengetahui kualitas bahan ajar terutama menyangkut komponen kelayakan isi, komponen penyajian dan komponen kebahasaan. Angket respon mahasiswa dimaksudkan untuk mengetahui respon mahasiswa terhadap pembelajaran fisika eksperimen berbasis proyek yang dilaksanakan; 2) Lembar observasi, untuk mengobservasi aktivitas mahasiswa selama proses pembelajaran untuk mengetahui keterlaksanaan penggunaan bahan ajar; 3) Instrumen tes keterampilan berpikir kritis untuk mengetahui pengaruh penggunaan bahan ajar fisika eksperimen berbasis proyek untuk meningkatkan keterampilan berpikir kritis mahasiswa calon guru.
Data yang diperoleh dalam penelitian ini berupa data kualitatif dan kuantitatif. Ada empat data yang dikumpulkan yaitu data hasil validasi ahli, data respon mahasiswa terhadap pembelajaran yang dilaksanakan, data hasil observasi keterlaksanaan pembelajaran dan data keterampilan berpikir kritis. Data yang bersifat kualitatif dianalisis secara deskriptif untuk menemukan kecenderungankecenderungan yang muncul pada saat penelitian sedangkan data kuantitatif dianalis dengan uji statistik.

Indikator keberhasilan penelitian ini adalah: 1) Kriteria keberhasilan dari bahan ajar yang telah dikembangkan, jika bahan ajar yang telah dikembangkan dalam kategori layak/baik digunakan tanpa revisi atau dengan sedikit revisi; 2) Mendapat respon positif dari mahasiswa; 3) Mahasiswa dapat menggunakan bahan ajar yang telah dikembangkan sehingga keterampilan berpikir kritis lebih meningkat.

\section{HASIL DAN PEMBAHASAN}

Pada tahap studi pendahuluan telah dilakukan analis potensi dan masalah pembelajaran Fisika Eksperimen II melalui kegiatan observasi dan wawancara dengan guru dan mahasiswa yang pernah menempuh matakuliah yang kemudian dikumpulkan datanya yang digunakan untuk pengembangan desain bahan ajar. Hasil observasi pembelajaran Fisika Eksperimen II menunjukkan bahwa metode yang digunakan menggunakan metode eksperimen. Mahasiswa melakukan eksperimen dengan menggunakan petunjuk praktikum dan setelah selesai melaksanakan praktikum diminta untuk membuat laporan hasil praktikum dan diberikan penilaian. Sebenarnya pada pembelajaran mata kuliah Fisika Eksperimen II ini mahasiswa dituntut untuk membuat alat/set alat yang digunakan untuk praktikum sesuai yang ada dalam petunjukkan praktikum. Pada saat membuat 
alat/set alat mahasiswa masih merasa kesulitan membuat sehingga hasil karya yang dibuat belum sempurna sehingga hasil praktikumnya belum memuaskan karena harus segera menyelesaikan tepat waktu. Kelebihan/potensi pembelajaran Fisika Eksperimen II ini adalah mahasiswa membuat alat/set alat sendiri tidak seperti pada pembelajaran mata kuliah lain yang ada praktikumnya seperti pada mata kuliah Fisika Dasar.

Hasil wawancara dengan guru mata pelajaran Fisika dan kajian kurikulum tahun 2013 bahwa pembelajaran Fisika di SMA perlunya menerapkan pembelajaran berbasis proyek. Guru merasa kesulitan melaksanakan pembelajaran tersebut dikarenakan sewaktu kuliah belum pernah melaksanakan pembelajaran proyek dan terbatasnya peralatan-peralatan yang ada dalam laboratorium.

Studi literatur tentang pembelajaran proyek dan keterampilan berpikir kritis juga dilakukan untuk melihat potensi apabila menerapkan pembelajaran proyek dalam perkuliahan Fisika Eksperimen II yang dapat meningkatkan keterampilan berpikir kritis serta memberikan pengalaman dan bekal pada mahasiswa sebagi calon guru agar dapat melaksanakan pembelajaran Fisika berbasis proyek sesuai tuntutan kurikulum tahun 2013. Hasil-hasil penelitian terdahulu, model pembelajaran yang efektif untuk meningkatkan keterampilan berpikir kritis (suatu persepsi guru) dapat dilaksanakan dengan menerapkan pembelajaran proyek (Sadia, 2008); pembelajaran proyek menjadi starting point budaya meneliti dan wawasan guru bertambah melalui pembelajaran proyek (Jarwanto, 2012); penerapan pembelajaran berbasis proyek berpengaruh terhadap keterampilan berpikir kritis dan sikap terkait sains peserta didik SMP (Kurniawan, 2012); terdapat perbedaan pemahaman konsep dan keterampilan berfikir kritis peserta didik antara peserta didik yang mengikuti pembelajaran berbasis proyek dan peserta didik yang belajar dengan pembelajaran konvensional (Sastrika, et al, 2013); penerapan model project based learning berbantuan media virtual berpengaruh terhadap penguasaan konsep peserta didik pada materi alat-alat optik (Suranti et al, 2016); penerapan pembelajaran berbasis proyek dapat mengoptimalkan hasil belajar peserta didik ranah keterampilan kognitif, keterampilan pemecahan masalah, dan keterampilan psikomotorik (Widodo, 2017).

Hasil studi literatur di atas digunakan untuk mengembangkan desain pembelajaran Fisika Eksperimen II berbasis proyek untuk meningkatkan keterampilan berpikir kritis mahasiswa calon guru. Telah dilakukan analisis komponen komponen pembelajaran berbasis proyek dan analisis indikator keterampilan berpikir kritis yang dapat dikembangkan dalam pembelajaran proyek.

Berdasarkan analisis potensi dan masalah dalam studi pendahuluan, dibuatlah desain bahan ajar Fisika Eksperimen II berbasis proyek yang dapat meningkatkan keterampilan berpikir kritis. Desain bahan ajar Fisika Eksperimen II berbasis proyek dikembangkan dari tahapan pembelajaran proyek yaitu: 1) Penentuan Judul Proyek, 2) Mendesain Perencanaan proyek, 3) Pelaksanaan Proyek, 4) Menguji coba hasil/produk, 5) Mengkomunikasikan hasil, 6) Mengevaluasi pengalaman. Bahan ajar yang dikembangkan juga menjelaskan pembelajaran Fisika Eksperimen berbasis proyek (BAB I), menjelaskan pembuatan proposal dan laporan akhir (BAB II), modul praktikum berbasis proyek (BAB III), penilaian proyek (BABIV) Bahan ajar yang telah dikembangkan divalidasi

untuk penilaian kelayakan dan masukan pakar untuk perbaikan desain bahan ajar. Butir-butir penilaian bahan ajar terdiri dari komponen kelayakan isi, komponen penyajian, komponen kebahasaan. hasil uji 
validasi bahan ajar untuk setiap komponen menunjukkan nilai komponen kelayaan isi 83,3\% dengan kriteria layak/baik untuk digunakan, nilai komponen penyajian 82,0 $\%$ dengan kriteria layak/baik untuk digunakan sedangkan nilai komponen kebahasaan $78,2 \%$ dengan kriteria layak/baik digunakan dengan revisi. Dari hasil validasi ahli dalam bahan ajar yang dikembangkan masih terdapat kekurangan dari komponen kebahasaan yang perlu disempurnakan sebelum digunakan untuk keperluan uji coba terbatas.

Bahan ajar yang sudah divalidasi dan diperbaiki kebahasaannya diujicobakan pada mahasiswa yang berjumlah 15 orang mahasiswa yang mengikuti perkuliahan Fisika Eksperimen II. Setelah selesai pembelajaran mahasiswa diminta untuk memberikan respon melalui angket untuk mengetahui keterbacaan bahan ajar dan kemudahan dalam mendapatkan informasi materi untuk melaksanakan pembelajaran proyek. Hasil uji coba terbatas melalui angket respon mahasiswa dapat dilihat pada Tabel 1.

Keterampilan berpikir kritis mahasiswa dinilai dari jawaban tes awal dan tes akhir setelah mengikuti pembelajaran. Indikator keterampilan berpikir kritis yang dinilai meliputi: 1) Keterampilan mengenal dan memecahkan masalah, 2) Keterampilan Menganalisis, 3) Keterampilan Mensintesis, 4) Keterampilan menyimpulkan, dan 5) Keterampilan Mengevaluasi atau Menilai.

Tabel 1. Hasil Respon Mahasiswa tentang Penggunaan Bahan Ajar

\begin{tabular}{|c|c|c|c|}
\hline Butir Penilaian & Prosentase & Rata- & Keterangan \\
\hline $\begin{array}{ll}\text { A. } & \text { Aspek } \\
& \text { keterbacaan } \\
\text { B. } & \text { Aspek } \\
& \text { kemudahan } \\
& \text { mengaskses } \\
& \text { materi }\end{array}$ & $77,3 \%$ & $78,5 \%$ & $\begin{array}{l}\text { Bahan Ajar } \\
\text { layak/baik } \\
\text { dipergunakan } \\
\text { dalam } \\
\text { pembelajaran } \\
\text { Fisika } \\
\text { Eksperimen dan } \\
\text { sedikit ada } \\
\text { perbaikan. }\end{array}$ \\
\hline
\end{tabular}

Perolehan skor rata-rata tes awal dan tes akhir keterampilan berpikir kritis mahasiswa dapat dilihat pada Tabel 2.

Tabel 2. Deskripsi Skor Keterampilan Berpikir Kritis Mahasiswa

\begin{tabular}{lcc}
\hline \multirow{2}{*}{$\mathrm{N}$} & Tes Awal & Tes Akhir \\
\cline { 2 - 3 } (jumlah mahasiswa ) & 15 & 15 \\
\hline Rata-rata & 38,1 & 69,8 \\
Standar Deviasi & 15,2 & 7,2 \\
Maksimum & 75 & 82 \\
Minimum & 15 & 57 \\
\hline
\end{tabular}

Dari tabel menunjukkan bahwa terjadi peningkatan rata-rata tes keterampilan berpikir kritis mahasiswa.

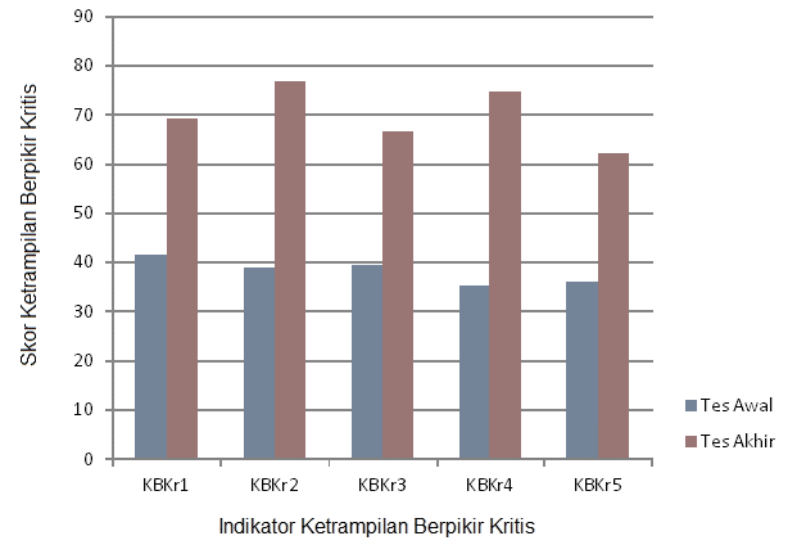

Gambar 2. Perbandingan Skor Tes Awal dan Tes Akhir Keterampilan Berpikir Kritis untuk setiap Indikator.

Apabila ditinjau dari skor indikator keterampilan berpikir kritis hasil tes awal dan akhir dapat dideskripsikan seperti pada Gambar 2. Ada lima indikator keterampilan berpikir kritis yang digunakan dalam penelitian ini, yaitu: KBKr1 Keterampilan Mengenal dan Memecahkan Masalah, $\mathrm{KBKr} 2$ Keterampilan Menganalisis, $\mathrm{KBKr} 3$ Keterampilan Mensintesis, KBKr4 Keterampilan menyimpulkan, dan KBKr5 Keterampilan Mengevaluasi atau Menilai.

Dari gambar dapat ditunjukkan bahwa terdapat peningkatan skor keterampilan berpikir kritis mahasiswa. Peningkatan skor tertinggi untuk indikator KBKr4 Keterampilan menyimpulkan sebesar 39,4 dan peningkatan terendah untuk 
indikator KBKr5 Keterampilan

Mengevaluasi atau Menilai sebesar 26,1.

Dengan demikian dapat diperoleh

hasil bahwa pembelajaran Fisika

Eksperimen dapat meningkatkan

keterampilan berpikir kritis mahasiswa. Dari

hasil observasi kegiatan pembelajaran mahasiswa sangat aktif mengikuti tahapantahapan pembembelajaran proyek dari tahapan penentuan judul proyek sampai tahap evaluasi proyek. Mahasiswa banyak berkonsultasi kepada pembimbing pada saat pelaksanaan proyek apabila menemui kendala dalam penyelesaian proyek. Pada saat presentasi hasil proyek mahasiswa saling bertanya dan berpendapat terhadap proyek yang dikerjakan oleh kelompok lainnya. Hal ini sejalan dengan teori pembelajaran proyek, peserta didik yang mengikuti pembelajaran berbasis proyek mendapatkan ruang lebih luas untuk belajar secara mandiri. Penerapan model pembelajaran berbasis proyek di kelas, di mulai dengan menetapkan tema proyek yaitu pengajar menetapkan tema proyek sesuai dengan materi yang dibahas. Menetapkan konteks belajar yaitu pengajar menyiapkan lingkungan belajar yang mendukung proses pembelajaran, misalnya menetapkan pembagian kelompok dalam diskusi. Konteks belajar yang dilakukan saat proses pembelajaran berlangsung, yaitu speserta didik melakukan inkuiry, seperti mampu membuat rumusan masalah, tujuan, menentukkan langkah langkah pembuatan percobaan. Merencanakan aktivitasaktivitas, yaitu peserta didik merencanakan proyek sesuai pada konteks belajar yang telah ditetapkan. Memroses aktivitasaktivitas, yaitu peserta didik membuat sketsa atau rancangan proyek yang akan digarap. Penerapan aktivitas aktivitas untuk menyelesaikan proyek, yaitu peserta didik mengerjakan proyek berdasarkan rancangan, membuat laporan/makalah terkait dengan proyek, mempresentasikan proyek, sedangkan pengajar menilai kinerja peserta didik. Pendidik lebih banyak berposisi sebagai pengarah, pembimbing, pemberi fasilitas, dan motivator dalam pembelajaran. Keadaan seperti ini sangat berpotensi untuk membangun konsep pada diri peserta didik secara mandiri. Konsep-konsep yang ditemukan melalui pembelajaran secara mandiri menjdi lebih bermakna.

Pembelajaran berbasis proyek merupakan metode yang menggunakan belajar kontekstual, dimana para peserta didik berperan aktif untuk memecahkan masalah, mengambil keputusan, meneliti, mempresentasikan, dan membuat dokumen. Pembelajaran berbasis proyek dirancang untuk digunakan pada permasalahan kompleks yang diperlukan peserta didik dalam melakukan investigasi dan memahaminya. Pembelajaran berbasis proyek memiliki kecocokan terhadap konsep inovasi pendidikan, terutama dalam hal sebagai berikut, pebelajar memproleh pengetahuan dasar (basic sciences) yang berguna dalam memecahkan masalah, pebelajar secara aktif dan mandiri dengan sajian materi terintegrasi dan relevan dengan kenyataan sebenarnya, pebelajar mampu berpikir kritis dan mengembangkan inisiatif.

Pembelajaran berbasis proyek memberikan kesempatan kepada peserta didik untuk bekerja berkelompok atau secara individual dan memberikan kesempatan untuk mengembangkan ide-ide dan solusisolusi realistik, sehingga pembelajaran berpusat pada peserta didik bukannya berpusat pada guru. Perubahan peran guru merupakan salah satu kunci dalam proses pembelajaran inovatif, dimana perubahan guru dari sebagai sumber pengetahuan dengan seorang fasilitator pembelajaran. Proses penyelidikan mendorong peserta didik untuk mengidentifikasi apa yang mereka sudah tahu, sehingga mereka dapat mengidentifkasi kebutuhan belajar mereka sendiri. Sifat eksplorasi dalam proses 
pembelajaran berbasis proyek penyelidikan memungkinkan peserta didik untuk melihat ide-ide dalam cara yang berbeda dan mempromosikan pemikiran kritis tentang masalah yang mereka hadapi. Model pembelajaran berbasis proyek memberikan peluang kepada peserta didiksecara bebas melakukan kegiatan untuk kegiatan percobaan, mengkaji literatur diperpustakaan, melakukan browsing di internet, dan berkolaborasi denganpendidik. Oleh karena itu sumber belajar menjadi lebih terbuka dan bervariasi, termasuk dalam mengeksplorasi lingkungan. Akibatnya, peserta didik akan belajar penuh dengan kesungguhan karena termotivasi oleh keinginan untuk menjawab pertanyaan yang telah diajukan sehingga pembelajaran menjadi lebih efektif dan bermakna.

Pembelajaran berbasis proyek juga dapat membantu peserta didik dalam mengembangkan banyak kemampuan seperti kemampuan fisik, intelektual, sosial, emosional, dan moral yang merupakan kemampuan peserta didik yang perlu dikembangkan. Terutama dalam hal ini kemampuan berpikir kritis peserta didik akan terlatih jika digunakan model pembelajaran berbasis proyek dalam pembelajaran. Hal ini sejalan dengan penelitian yang menyimpulkan bahwa pembelajaran berbasis proyek dapat menuntun seseorang untuk berlatih dan memahami berpikir kompleks dan mengetahui bagaimana mengintegrasikannya dalam bentuk keterampilan yang sering dikaitkan dengan kehidupan nyata, mampu memanfaatkan pencarian berbagai sumber, berpikir kritis, dan mempunyai keterampilan pemecahan masalah dengan baik, akan mampu melengkapi proyek mereka (Sastrika, et al, 2013). Penugasan-penugasan pada pembelajaran berbasis proyek akan merangsang seluruh indra peserta didik untuk mengerjakan tugas tugas ataupun permasalahan-permasalahan yang diberikan oleh pengajar, sehingga peserta didik akan terbiasa aktif dan kreatif dalam menyelesaikan permasalahan yang ada (Nurohman, 2008). Dengan demikian, model pembelajaran berbasis proyek memberikan hasil keterampilan berpikir kritis peserta didik akan meningkat.

\section{PENUTUP}

Berdasarkan hasil penelitian yang telah dilakukan, maka dapat disimpulkan sebagai berikut:

1. Bahan ajar Fisika Eksperimen berbasis proyek yang telah dikembangkan layak/baik digunakan dalam pembelajaran dan memenuhi uji validasi oleh ahli untuk komponen kelayakan isi, penyajian dan kebahasaan dengan kategori baik.

2. Respon mahasiswa setelah menggunakan bahan ajar sangat baik untuk menunjang dan melengkapi bahan ajar pada saat perkuliahan Fisika Eksperimen II.

3. Bahan ajar yang diuji cobakan dalam pembelajaran Fisika Eksperimen II mampu meningkatkan keterampilan berpikir kritis mahasiswa dilihat dari hasil tes awal dengan rerata skor 38,1 dan hasil tes akhir dengan rerata skor 69,8 .

Bahan ajar Fisika Eksperimen II yang telah dikembangkan dapat digunakan sebagai acuan untuk mengembangkan bahan ajar matakuliah atau materi pembelajaran yang memiliki karakteristik sama atau hampir sama.

\section{UCAPAN TERIMAKASIH}

Penulis mengucapkan terimakasih dalam penelitian maupun publikasi ilmiah, termasuk donatur penelitian kepada Universitas Mataram yang membantu penelitian ini lewat sumber dana DIPA PNPB Tahun Anggaran 2017. 


\section{REFERENSI}

Jarwanto, A. (2012) Pembelajaran proyek mata Pelajaran Fisika di SMA sebagai starting point pembentukan budaya meneliti. Jakarta: Seminar Nasional Fisika.

Kurniawan, A. 2(012). Pengaruh Model Pembelajaran Berbasis Proyek Terhadap Keterampilan Berpikir Kritis dan Sikap Terkait Sains Peserta didik SMP (Studi Esperimen di SMP Negeri 4 Singaraja). Jurnal Pendidikan IPA, 2(1).

Meyers, C. (1986). Teaching students Think Critically. London: Jossey-Bass Publishers.

Nurohman S. (2008). Pendekatan project based learning sebagai upaya internalisasi scientific method bagi mahasiswa calon guru fisika. Yogyakarta: Universitas Negeri Yogyakarta.

Purwanto Widodo G, Joko (2017) Pengembangan dan Implementasi perangkat Pembelajaran Berbasis Proyek - Innovation of Vocational Technology Education,ejournal.upi.edu.

Sadia, I. W. (2008). Model pembelajaran yang efektif untuk meningkatkan keterampilan berpikir kritis (suatu persepsi guru). Jurnal pendidikan dan pengajaran Undiksha, 2(2): 19237.

Sastrika, Ida Ayu Kade, Wayan Sadia, and I. Wayan Muderawan. (2013). Pengaruh Model Pembelajaran Berbasis Proyek Terhadap Pemahaman Konsep Kimia dan Keterampilan Berpikir Kritis. Jurnal Pendidikan IPA, 3(1).

Schafersman, Steven D. (2006). An Introduction to Critical Thinking. http://www.freeinquiry.com/criticalthinking.html.

Sugiyono, (2008). Metode Penelitian kuantitatif, kualitatif dan $R \& D$. Jakarta: Alfabeta
Suranti, N. M. Y., Gunawan, dan Sahidu, H. (2016). Pengaruh Model Project Based Learning Berbantuan Media Virtual Terhadap penguasaan Konsep Peserta Didik Pada Materi Alat-alat Optik, Jurnal Pendidikan Fisika dan Teknologi, 2(2), 73 - 79. 